\title{
PENGEMBANGAN PERANGKAT PEMBELAJARAN BERORIENTASI PROSES SAINS UNTUK MENINGKATKAN KETERAMPILAN ILMIAH
}

\author{
Musdar M \\ Universitas Sulawesi Barat \\ e-mail: musdar@unsulbar.ac.id
}

\begin{abstract}
Abstrak
Penelitian ini bertujuan untuk memperoleh perangkat pembelajaran fisika berbasis keterampilan proses sains yang berkualitas, mengetahui peningkatan keterampilan ilmiah peserta didik setelah diajar dengan menggunakan perangkat pembelajaran berbasis keterampilan proses sains, dan mengetahui respon peserta didik terhadap perangkat pembelajaran berorientasi keterampilan proses sains yang diterapkan. Perangkat yang dikembangkan adalah Rencana Pelaksanaan Pembelajaran (RPP), Materi Ajar Peserta Didik (MAPD), dan Lembar Kegiatan Peserta Didik (LKPD). Pengembangan perangkat ini menggunakan model Kemp, Morisson dan Ross yang terdiri dari sembilan unsur pengembangan yakni instructional problems, learner characteristic, task analysis, instructional objectives, sequence content, instructional strategies, instructional delivery, evaluation instrument, dan instructional resources. Uji pengembangan perangkat dilaksanakan pada peserta didik kelas VIII. SMP IT Al-Fityan School Kab Gowa. Berdasarkan hasil analisis data diperoleh bahwa (i) Kualitas perangkat pembelajaran fisika (RPP, MAPD, dan LKPD) berorientasi keterampilan proses sains telah memenuhi kriteria kelayakan, kepraktisan, dan keefektifan. (ii) peningkatan keterampilan ilmiah peserta didik setelah perangkat berorientasi keterampilan proses sains diterapkan sebesar 0,72 atau termasuk dalam kategori tinggi (iii) respon peserta didik terhadap perangkat dan pelaksanaan kegiatan pembelajaran sebesar $85,71 \%$ berada pada kategori sangat positif.
\end{abstract}

Kata Kunci: Keterampilan Proses Sains, Keterampilan Ilmiah, Model Kemp

\section{DEVELOPMENT OF SCIENCE PROCESS ORIENTED LEARNING DEVICES TO IMPROVE SCIENTIFIC SKILLS}

\begin{abstract}
This study aims to obtain quality physics learning tools based on science process skills, determine the improvement of students 'scientific skills after being taught using science process skills-based learning tools, and determine the students' responses to skills-oriented learning tools. applied science processes. The tools developed are the Learning Implementation Plan (RPP), Student Teaching Materials (MAPD), and Student Activity Sheets (LKPD). The development of this device uses the Kemp, Morisson and Ross model which consists of nine elements of development, namely instructional problems, learner characteristics, task analysis, instructional objectives, sequence content, instructional strategies, instructional delivery, evaluation instruments, and instructional resources. The device development test was carried out on class VIII students. SMP IT Al-Fityan School, Gowa Regency. Based on the results of data analysis, it was found that (i) the quality of physics learning tools (RPP, MAPD, and LKPD) oriented to science process skills had met the criteria for feasibility, practicality, and effectiveness. (ii) the increase in the scientific skills of students after the science process skills oriented device was applied was 0.72 or included in the high category (iii) the response of students to the device and the implementation of learning activities was $85.71 \%$ in the very positive category.
\end{abstract}

Keywords: Science Process Skills, Scientific Skills, Kemp Model 


\section{PENDAHULUAN}

Pembelajaran merupakan bagian atau elemen yang memiliki peran sangat dominan untuk mewujudkan kualitas baik pada proses maupun output (hasil) pendidikan. Konsekuensinya proses pembelajaran harus dilaksanakan secara tepat, ideal dan proporsional. Pembelajaran pada hakikatnya merupakan sebuah sistem, artinya terciptanya sebuah pembelajaran disebabkan karena adanya berbagai komponen atau faktor yang berinteraksi.

Sains dalam hal ini fisika sebagai suatu disiplin ilmu yang hakikatnya merupakan pengetahuan yang berdasarkan fakta, hasil pemikiran para ahli dan hasilhasil eksperimen yang dilakukan para ahli. Selanjutnya perkembangan fisika ditunjukkan oleh produk ilmiah berupa fakta, teori, konsep dan generalisasi. Seiring dengan itu berkembang juga metode ilmiah dan sikap ilmiah.

IPA dalam proses pembelajarannya lebih diarahkan pada pengembangan kemampuan intelektual serta keterampilan berpikir dan kemampuan pemahaman konsep yang lebih baik. Hal ini ditujukan pada peserta didik sebagai bekal untuk pendidikan selanjutnya.

IPA dapat dipandang sebagai tiga hal yang sama pentingnya, yaitu serangkaian proses sistematis untuk mendapatkan informasi tentang alam semesta, kumpulan pengetahuan (produk), nilai dan sikap yang melekat pada orang yang menggunakan proses ilmiah untuk mendapatkan pengetahuan. "Science is the knowledge gathered through a group of processes that people use systematically to make discoveries about the natural world." Sains adalah pengetahuan yang dikumpulkan dari suatu proses yang digunakan secara sistematis untuk penemuan tentang dunia alam [1]. Sains diperoleh tidak melalui fakta (produk ilmiah) saja, tetapi juga melalui metode ilmiah dan keterampilan ilmiah yang timbul [2].

Dari hasil wawancara yang dilakukan pada beberapa pendidik, dalam kaitannya dengan pembelajaran, pada umumnya proses pembelajaran masih berpusat kepada pendidik, jarang diadakan praktikum, kurang mengaitkan materi pembelajaran dengan pengalaman sehari-hari peserta didik, pertanyaan-pertanyaan yang diajukan hanya terbatas pada soal hitungan yang diberikan sehingga prinsip sains yang melibatkan peserta didik secara aktif dalam proses berpikir dan berperilaku ilmiah belum terlaksana dengan baik.

Penelitian mengembangkan perangkat pembelajaran fisika dalam pencapaian keterampilan proses sains berupa RPP, LKPD, dan tes keterampilan ilmiah menemukan bahwa perangkat pembelajaran fisika yang telah dikembangkan dapat digunakan dalam pencapaian keterampilan proses sains peserta didik. Menurut teori yang dikemukakannya bahwa pembelajaran fisika, selain dapat meningkatkan hasil belajar juga dapat mengaitkan materi pembelajaran dengan kehidupan nyata sehari-hari yang membiasakan mengajarkan langkah-langkah yang dapat digunakan dalam berketerampilan ilmiah [3].

Penerapan keterampilan proses sains melalui model pembelajaran masalah untuk meningkatkan prestasi belajar peserta didik. Hasil penelitiannya menunjukkan bahwa peningkatan prestasi belajar ranah kognitif peserta didik berdasarkan nilai rata-rata gain ternormalisasi pada tiap seri termasuk dalam kriteria sedang. Adapun kategori profil keterampilan proses sains peserta didik selama pembelajaran berlangsung adalah cukup pada seri ke-1 $(51,16 \%)$, baik pada seri ke-2 $(60,40)$, dan cukup pada seri ke-3 $(49,25)[4]$.

Pelatihan keterampilan proses sains melalui model direct instruction dalam pencapaian hasil belajar fisika siswa SMA Negeri 1 Majene. Hasil penelitiannya menunjukkan bahwa pelatihan keterampilan proses sains dapat meningkatkan hasil belajar fisika peserta didik [5]. Oleh karena itu hasil penelitian dapat disimpulkan bahwa keterampilan keterampilan proses sains dapat 
meningkatkan prestasi belajar peserta didik baik dari aspek kognitif maupun aspek psikomotorik, dalam hal ini keterampilan ilmiah.

Keterampilan proses merupakan keseluruhan keterampilan ilmiah yang terarah (baik kognitif maupun psikomotorik) yang dapat digunakan untuk menemukan suatu konsep atau prinsip atau teori, untuk mengembangkan konsep yang telah ada sebelumnya, ataupun untuk melakukan penyangkalan terhadap suatu penemuan/klarifikasi [6]. Keterampilan proses adalah keterampilan yang diperoleh dari latihan kemampuan mental, fisik, dan sosial yang mendasar sebagai penggerak kemampuan-kemampuan yang lebih tinggi. Kemampuan mendasar yang telah dikembangkan terlatih lama kelamaan akan menjadi suatu keterampilan. [7]

Klasifikasi keterampilan proses sains terdiri atas keterampilan proses dasar dan keterampilan proses terpadu. Keterampilan proses dasar merupakan fondasi untuk melatihkan proses terpadu yang lebih kompleks [8]. Keterampilan-keterampilan proses sains yang lain adalah: penggunaan bilangan (Numbering), penafsiran data (Interpreting Data), Pengontrolan variabel (Controlling Variables), perumusan hipotesis (Hypothesizing), Pendefinisian Secara Operasional (Defining Operationally), membangun model (Formulating Model) [9]. Keterampilanketerampilan proses sains adalah keterampilan-keterampilan yang dipelajari peserta didik pada saat mereka melakukan inkuiri ilmiah [10].

Keterampilan proses sains (KPS) adalah kemampuan peserta didik untuk menerapkan metode ilmiah dalam memahami, mengembangkan dan menemukan ilmu pengetahuan [11]. Secara garis besar proses keterampilan ilmiah terdiri atas, pengamatan dan observasi, fakta dan data, merumuskan masalah, merumuskan hipotesis, melakukan eksperimen, menguji hipotesis, dan jawaban atas masalah [12].

Bertolak dari uraian tersebut peneliti tertarik untuk mengembangkan perangkat pembelajaran berorientasi keterampilan proses sains. Perangkat pembelajaran yang akan dikembangkan adalah Rencana Pelaksanaan Pembelajaran (RPP), Materi Ajar Peserta Didik (MPD), Lembar Kerja Peserta Didik (LKPD), Tes Keterampilan Ilmiah (TKI). Perangkat yang dikembangkan akan diujikan untuk mengetahui apakah perangkat efektif dalam meningkatkan keterampilan ilmiah.

\section{METODE PENELITIAN}

Jenis penelitian Penelitian ini dapat digolongkan dalam jenis penelitian pengembangan dimana hasil penelitian disampaikan secara deskriptif. Perangkat yang dikembangkan terdiri dari Rencana Pelaksanaan Pembelajaran (RPP), Materi Ajar Peserta Didik (MAPD), Lembar Kegiatan Peserta Didik (LKPD) dan Tes Keterampilan Ilmiah (TKI). Hasil dari penerapan perangkat pembelajaran dan pengamatannya disampaikan secara deskriptif, sementara pengujian datanya dibandingkan dengan suatu kriteria atau standar yang sudah ditetapkan pada waktu penyusunan desain penelitian.

Subjek dalam penelitian ini adalah peserta didik kelas VIII. B SMP Negeri 1 Bulukumba yang terdiri dari 23 peserta didik pada semester genap tahun Pelajaran 2018/2019. Desain pengembangan perangkat pembelajaran menggunakan perancangan model Kemp, yang rancangannya seperti pada gambar 1 . 


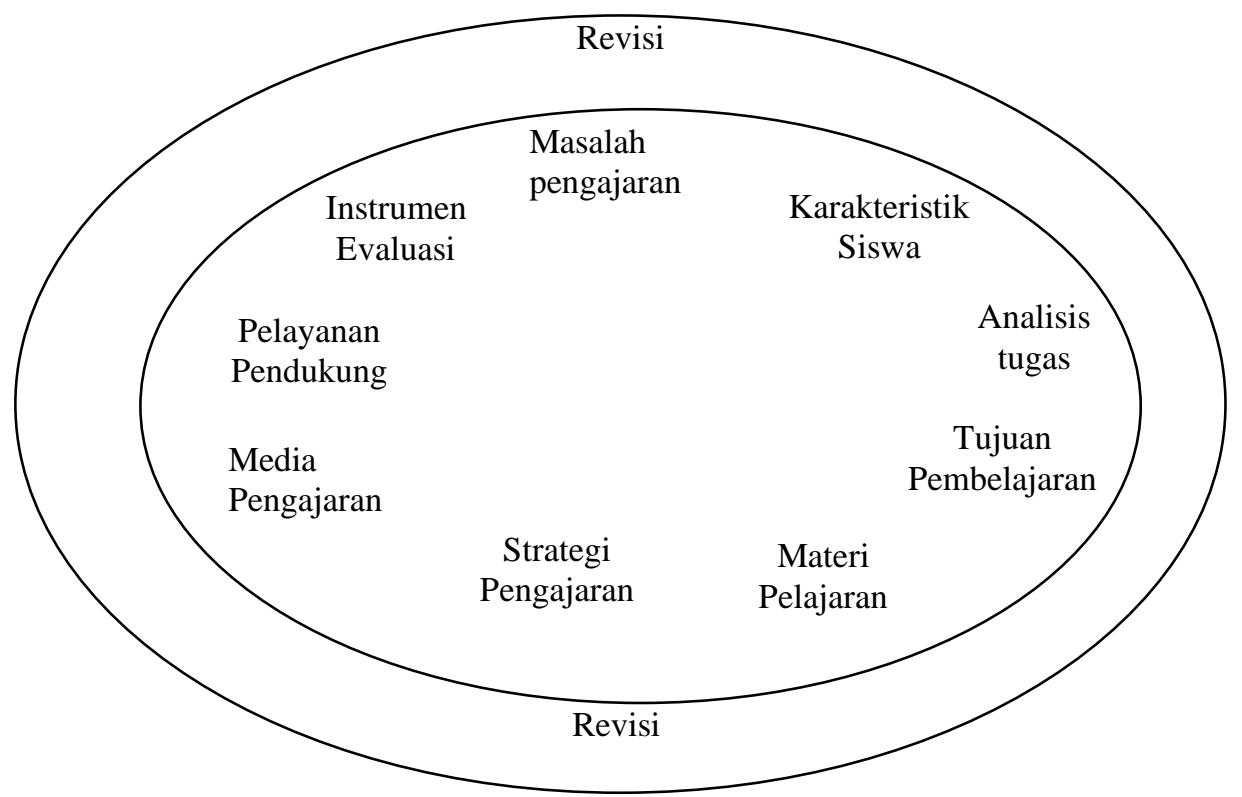

Gambar 1. Model Kemp, Morisson dan Ros

Pada model Kemp ini, seorang pengembang dapat memulai proses pengembangannya dari komponen manapun. Namun karena kurikulum yang berlaku secara nasional di Indonesia berorientasi kepada tujuan, maka seyogyanya proses pengembangan itu dapat dimulai dari tujuan. [13]

Prosedur penelitian ini terbagi dalam beberapa tahapan yaitu: tahap persiapan, tahap pelaksanaan, dan tahap pelaporan. Pada tahap persiapan hal-hal yang dilakukan meliputi: mengurus surat izin penelitian, mengkaji teori-teori tentang keterampilan proses sains, menyusun perangkat pembelajaran, dan menganalisis kurikulum untuk memilih standar kompetensi, kompetensi dasar, indikator, serta materi yang akan diajarkan. Pada tahap pelaksanaan hal-hal yang dilakukan meliputi: menentukan subjek dan lokasi penelitian, menentukan waktu pelaksanaan penelitian, melaksanakan penelitian dengan menggunakan perangkat pembelajaran berorientasi keterampilan proses sains dengan peneliti sebagai pendidik dan dibantu oleh dua observer, dan memberikan tes akhir kepada peserta didik sebelum dan setelah pembelajaran berlangsung. Pada tahap pelaporan adalah menganalisis data hasil penelitian dan membuat laporan ilmiah.

Dalam penelitian ini menggunakan model pengembangan perangkat model Kemp. Model pengembangan ini terdiri dari beberapa tahapan yaitu: dari beberapa tahapan, yakni : (1) identifikasi masalah pelajaran, (2) analisis karakteristik peserta didik, (3) analisis tugas, (4) menyusun urutan konsep, (5) merumuskan tujuan pembelajaran, (6) merancang strategi pembelajaran, (7) pemilihan media/sumber belajar, (8) Penyajian materi pelajaran, (9) menyusun instrumen evaluasi. Tahapan revisi dapat dilakukan secara terus menerus untuk menghasilkan perangkat yang baik.

\section{Identifikasi Masalah Pembelajaran}

Tahap ini bertujuan untuk mengidentifikasi kesenjangan antara kurikulum yang berlaku dengan fakta yang terjadi di lapangan, baik yang menyangkut model, pendekatan, metode, teknik, maupun strategi yang digunakan guru dalam mencapai tujuan pembelajaran.

\section{Analisis Peserta Didik}

Analisis karakteristik siswa bertujuan untuk dijadikan gambaran awal dalam mengembangkan perangkat. Karakteristik 
tersebut berupa pengetahuan awal peserta didik, usia peserta didik, sikap dalam proses pembelajaran, dan kemampuan akademik peserta didik.

\section{Analisis Tugas}

Analisis tugas merupakan prosedurprosedur yang dilakukan untuk menentukan isi suatu pengajaran [14]. Dalam tahap ini, hal yang dilakukan adalah mengidentifikasi materi dan menganalisis komponen tugas belajar yang terkait dalam pencapaian tujuan pembelajaran. Hasil analisis tugas nantinya diimplementasikan ke dalam RPP, Materi Ajar, dan LKPD.

\section{Menyusun Urutan Konsep}

Tujuan langkah ini adalah untuk menetapkan urutan konsep yang akan dibahas dalam proses belajar mengajar.

\section{Tujuan Pembelajaran}

Tujuan pembelajaran dilakukan dimaksudkan untuk digunakan sebagai alat dalam mendesain kegiatan pembelajaran, serta kerangka dalam merencanakan evaluasi hasil belajar peserta didik.

\section{Strategi Pembelajaran}

Untuk mencapai tujuan pembelajaran dibutuhkan suatu strategi pembelajaran yang sesuai dengan materi yang akan diajarkan serta tujuan yang akan dicapai. Strategi yang ditetapkan untuk mencapai tujuan pembelajaran tersebut adalah tanya jawab, diskusi, serta demonstrasi.

\section{Sumber Pembelajaran}

Pemilihan sumber pembelajaran harus disesuaikan dengan hasil analisis tujuan, analisis karakteristik siswa serta analisis tugas yang telah dilakukan pada tahap sebelumnya. Memilih alat dan bahan harus berdasarkan tujuan yang telah dirumuskan. Media yang digunakan adalah papan tulis, spidol, LCD, laptop, materi ajar yang dikembangkan, LKPD. Adapun alat dan bahan yang digunakan berupa alat dan bahan yang sesuai dengan judul praktikum yang direncanakan.

\section{Penyajian Pembelajaran}

Dalam tahap penyajian pembelajaran, yang dilakukan adalah menentukan metode yang tepat untuk menyampaikan materi pembelajaran. Penyajian materi pembelajaran tersebut akan terangkum dalam Rencana Pelaksanaan Pembelajaran (RPP).

\section{Instrumen Evaluasi}

Instrumen evaluasi merupakan alat yang digunakan untuk mengukur penguasaan siswa sebelum dan setelah berlangsungnya proses pembelajaran. Instrumen yang digunakan harus sesuai dengan tujuan pembelajaran khusus yang telah dirumuskan. Instrumen dalam penelitian ini adalah instrumen yang dirancang untuk mengetahui peningkatan keterampilan ilmiah peserta didik setelah diajar dengan menggunakan perangkat pembelajaran berorientasi keterampilan proses sains.

\section{Teknik analisis data}

Validitas format perangkat pembelajaran akan ditentukan dengan mencocokkan ratarata total validitas seluruh butir penilaian dengan kategori kevalidan perangkat, sebagai berikut:

Tabel 1. Interpretasi nilai validasi ahli

\begin{tabular}{cc}
\hline Nilai & Kategori \\
\hline $3,5 \leq \mathrm{Va} \leq 4$ & Sangat valid \\
$2,5 \leq \mathrm{Va}<3,5$ & Valid \\
$1,5 \leq \mathrm{Va}<2,5$ & Cukup valid \\
$\mathrm{V}_{\mathrm{a}}<1,5$ & Tidak valid \\
\hline
\end{tabular}

Analisis yang digunakan untuk mengetahui tingkat reliabilitas oleh dua orang pengamat validator (pada aspek yang sama) pada lembar instrumen perangkat pembelajaran, digunakan "interobsever agreements" dengan analisis statistik "percentage of agreements" [15] [16].

Untuk persentase banyaknya peserta didik yang memberikan respon pada setiap kategori yang ditanyakan dalam lembar angket menggunakan rumus sebagai berikut: 


$$
P R S=\frac{\sum A}{\sum B} x 100 \%
$$

Data kinerja peserta didik dianalisis dengan menggunakan persentase :

$$
\%=\frac{\sum \text { skor }}{\sum \text { skor maksimal }} \times 100 \%
$$

Interpretasi hasil data kinerja keterampilan ilmiah peserta didik adalah sebagai berikut:

Tabel 2. Interpretasi keterampilan ilmiah Peserta didik

\begin{tabular}{c|c}
\hline $\begin{array}{c}\text { Persentase } \\
\text { peserta didik }\end{array}$ & Interpretasi \\
\hline$<20,00$ & Sangat Kurang \\
$21,00-40,00$ & Kurang \\
$41,00-60,00$ & Cukup Baik \\
$61,00-80,00$ & Baik \\
$81,00-100$ & Sangat Baik \\
\hline
\end{tabular}

Untuk mengetahui kategori peningkatan keterampilan ilmiah peserta didik yang terjadi setelah pembelajaran dihitung dengan rumus $N$-gain sebagai berikut,

$$
g=\frac{\text { Skor Postest-Skor Pretest }}{S_{\text {maks }}-\text { Skor Pretest }}
$$

Tabel 3. Kategori Tingkat $N$-gain

\begin{tabular}{cc}
\hline Batasan & Kategori \\
\hline $\mathrm{g}>0,7$ & Tinggi \\
$0,3 \leq \mathrm{g} \leq 0,7$ & Sedang \\
$\mathrm{g}<0,3$ & Rendah \\
\hline
\end{tabular}

Penelitian ini termasuk ke dalam jenis penelitian pengembangan (research and development) yang bertujuan untuk menghasilkan perangkat pembelajaran yang berkualitas. Selain itu, dilihat pula sejauh mana pembelajaran berorientasi keterampilan proses sains sebagai alternatif model pembelajaran yang digunakan dalam peningkatan keterampilan ilmiah peserta didik.

Setelah perangkat dikembangkan melalui model Kemp, untuk mengetahui kevalidannya maka perangkat dinilai oleh dua orang pakar fisika. Hasil penilaian dari dua validator ahli diperoleh bahwa dari keseluruhan perangkat pembelajaran yang dikembangkan diperoleh nilai valid dan reliabel seperti pada gambar 2. Kevalidan tergambar dari hasil penilaian dua validator dimana semua menyatakan perangkat tersebut valid dari segi format RPP, Bahasa, serta isi dan tujuan untuk Rencana Pelaksanaan Pembelajaran, Format bahan ajar peserta didik, isi bahan ajar, bahasa dan tulisan, serta manfaat dan kegunaan untuk Materi Ajar Peserta Didik (MAPD), dari segi format, isi, bahasa, manfaat kegunaan untuk Lembar Kerja Peserta Didik (LKPD). Rata-rata nilai kevalidan dari ketiga perangkat.

\section{HASIL DAN DISKUSI}

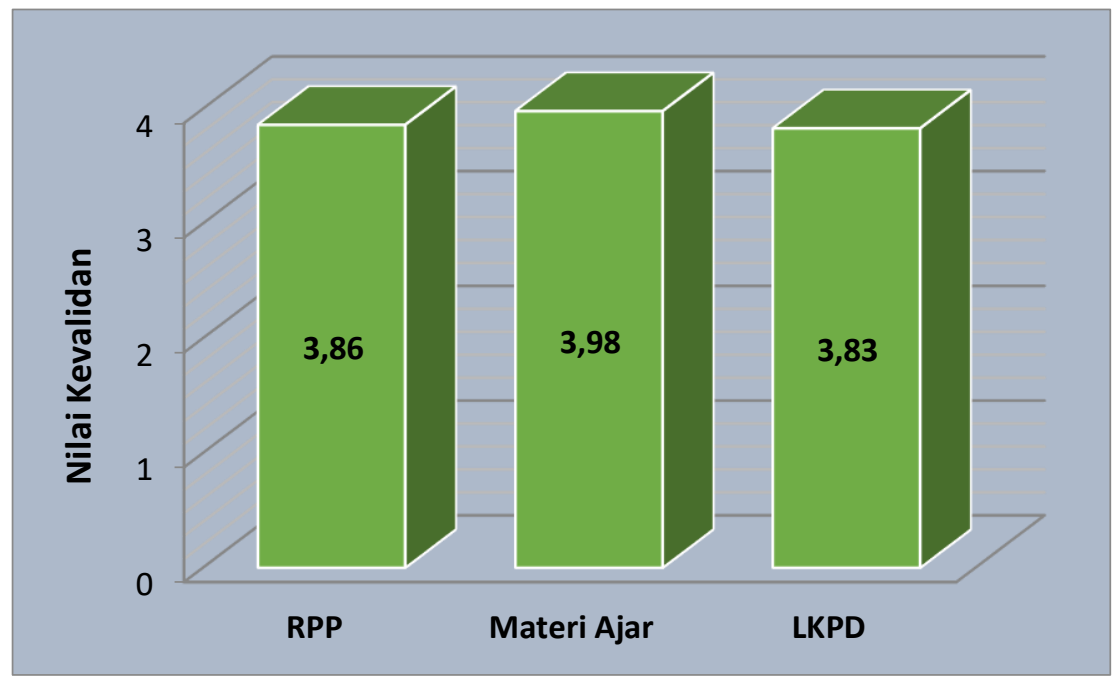

Gambar 2. Hasil Validasi Perangkat Pembelajaran 


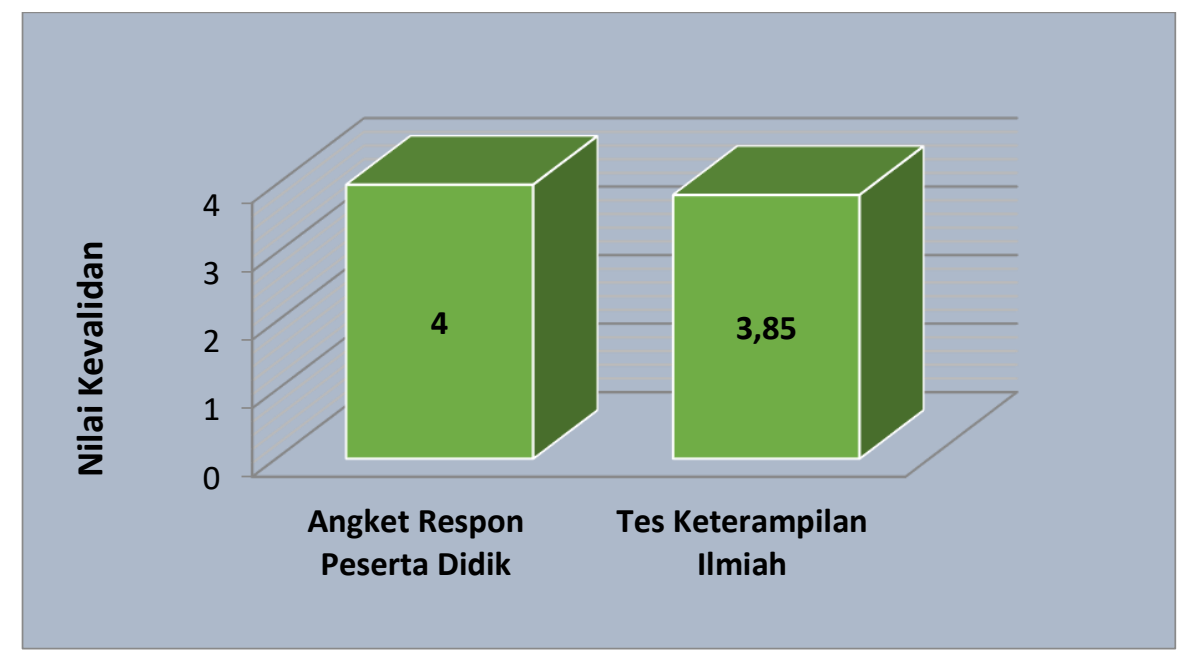

Gambar 3. Hasil validasi instrumen

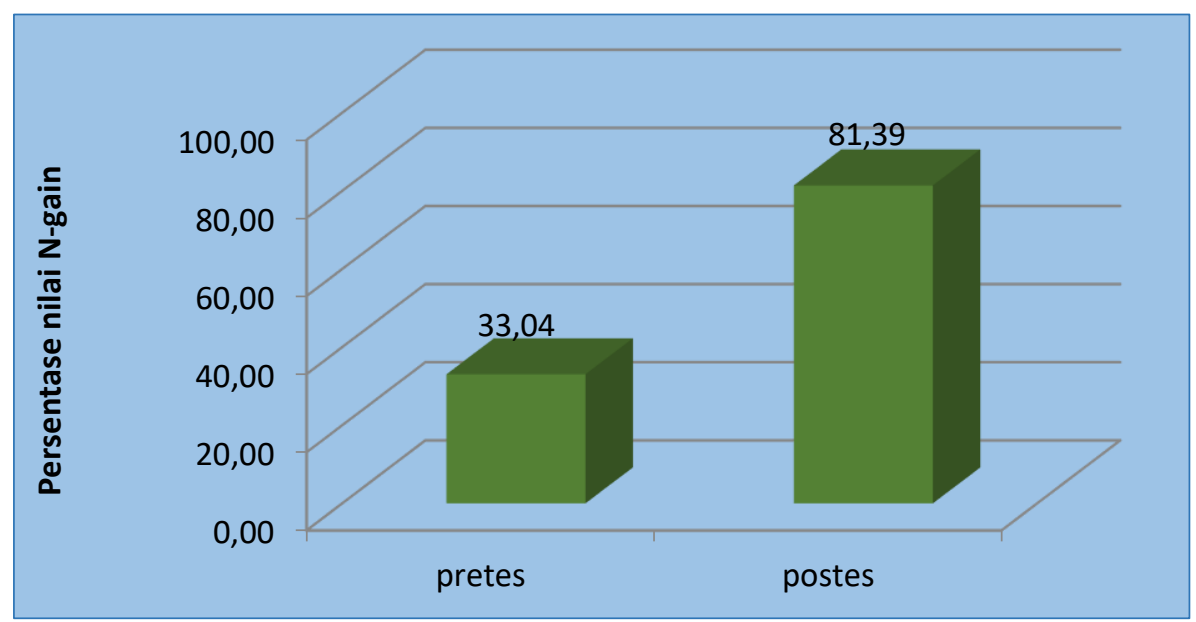

Gambar 4. Nilai persentase $N$-gain rata-rata skor pretest dan postes

Tabel 4. Hasil respon peserta didik terhadap pembelajaran berorientasi keterampilan proses sains

\begin{tabular}{cccc}
\hline No & Aspek & $\begin{array}{c}\text { Rata-rata } \\
\text { Persentase }\end{array}$ & Keterangan \\
\hline 1 & Materi Ajar & 83,00 & SP \\
2 & LKPD & 85,57 & SP \\
3 & Proses Pembelajaran & 88,17 & SP \\
\hline & Total rata-rata & 85,58 & SP \\
\hline
\end{tabular}

Gambar 3 menunjukkan hasil validasi terhadap instrumen menunjukkan bahwa seluruh instrumen yang akan digunakan memperoleh nilai valid. Instrumen tersebut yaitu angket respon peserta didik, serta tes keterampilan ilmiah. Pandangan kedua ahli menyatakan bahwa perangkat yang dikembangkan serta instrumen yang akan digunakan dalam penelitian dapat digunakan dengan sedikit revisi, sehingga dari segi aspek kevalidan perangkat pembelajaran pendekatan proses sains ini telah terpenuhi.

Analisis perhitungan reliabilitas diperoleh bahwa semua perangkat serta instrumen yang dikembangkan dinyatakan reliabel. Hal ini berarti perangkat pembelajaran serta instrumen penelitian 
layak digunakan dalam penelitian. Perangkat dan instrumen dikatakan baik jika memenuhi koefisien reliabilitas sebesar $\geq 0,75$ atau $\geq 75 \%$ [19].

Secara umum hasil penilaian peserta didik terhadap ketiga aspek tadi adalah sangat positif seperti pada tabel 4. Dari hasil tersebut, dapat diartikan bahwa proses pembelajaran dengan menggunakan pendekatan keterampilan proses sains untuk meningkatkan keterampilan ilmiah beserta perangkatnya diterima positif oleh peserta didik.

Peningkatan keterampilan ilmiah peserta didik dianalisis dengan menggunakan rumus n-gain. Berdasarkan hasil analisis uji n-gain diperoleh bahwa terdapat peningkatan keterampilan ilmiah peserta didik setelah diajar dengan menggunakan perangkat berorientasi pendekatan proses sains. Hal ini terlihat pada gambar 4, dari persentase perolehan skor pada postes sebesar $81,09 \%$ meningkat dibanding skor pretes dengan 32,91\%. Terdapat peningkatan sebesar $48,18 \%$. Peningkatan keterampilan ilmiah tersebut memperoleh nilai $\mathrm{N}$-gain sebesar 0,72 atau termasuk dalam kategori tinggi.

Dari hasil analisis uji gain peningkatan keterampilan ilmiah setiap indikator diperoleh nilai gain yakni: (1) Indikator pengamatan/observasi, peserta didik mengalami peningkatan, dengan nilai sebesar 0,79 atau berada pada kategori tinggi, (2) Indikator mendapatkan fakta peserta didik mengalami peningkatan, dengan nilai sebesar 0,74 atau berada dalam kategori tinggi, (3) Indikator merumuskan masalah peserta didik memperoleh peningkatan, dengan nilai sebesar 0,65 atau berada pada kategori sedang, (4) Indikator merumuskan hipotesis peserta didik mengalami peningkatan sebesar 0,74 atau berada pada kategori tinggi, (5) indikator melakukan eksperimen peserta didik mengalami peningkatan sebesar 0,63 atau berada pada kategori sedang, kemudian (6) Indikator menguji hipotesis juga mengalami peningkatan, dengan nilai sebesar 0,61 atau berada pada kategori sedang, dan yang ke (7) Indikator membuat kesimpulan mengalami peningkatan sebesar 0,74 atau berada pada kategori tinggi.

\section{SIMPULAN DAN SARAN}

Berdasarkan hasil penelitian yang telah dilakukan maka dapat disimpulkan sebagai bahwa kualitas perangkat pembelajaran yang dihasilkan dalam penelitian ini meliputi: rencana Pelaksanaan Pembelajaran, materi Ajar Peserta Didik, lembar Kegiatan Peserta Didik berorientasi keterampilan proses sains untuk meningkatkan keterampilan ilmiah peserta didik, berdasarkan hasil validasi menunjukkan bahwa perangkat pembelajaran memenuhi kriteria valid dan reliabel. Keterampilan Ilmiah peserta didik setelah diajar menggunakan perangkat yang telah dikembangkan mampu ditingkatkan dengan kategori peningkatan tinggi. Respon peserta didik terhadap perangkat pembelajaran berorientasi keterampilan proses sains setelah diajar menggunakan perangkat tersebut sangat positif.

\section{DAFTAR PUSTAKA}

[1] Abrucasto, J. 1996. Teaching Children Science. Needham Heights, Massachussets: Allyn and Bacon.

[2] Carin A.A. 1993. Teaching Modern Science. New York : Macmillan.

[3] Murni. 2013. Pengembangan Perangkat Pembelajaran Berorientasi Keterampilan Konstruktivisme untuk Meningkatkan Keterampilan Proses Peserta Didik. Tesis. PPs UNM Makassar.

[4] Ulfatonah. 2010. Penerapan Keterampilan Proses Sains Melalui Model Pembelajaran Berbasis Masalah untuk Meningkatkan Prestasi Belajar Peserta Didik. Tesis tidak diterbitkan, Makassar. PPs UNM Makassar.

[5] Muliadi. 2011. Pelatihan Keterampilan Proses Sains Melalui Model Direct Instruction dalam 
Pencapaian Hasil Hasil Belajar Fisika Siswa SMA Negeri 1 Majene. Tesis tidak diterbitkan, Makassar. PPs UNM Makassar.

[6] Indrawati. 1999. Keterampilan Proses Sains: Tinjauan Kritis Dari Teori ke Praktis. Bandung: Dirjen Pendidikan Dasar dan Menengah.

[7] Trianto. 2010. Mendesain Model Pembelajaran Inovatif-Progresif. Jakarta: Kencana Prenada Media Group.

[8] Nur, M. dan Samani, M. 1998. Teori Pembelajaran IPA dan Hakikat Pendekatan Keterampilan Proses. Jakarta: Depdikbud.

[9] Arends, R. I. 2000. Classroom Instruction and Management. New York: McGraw-Hill.

[10] Nur, M. 2003. "Keterampilanketerampilan Proses Sains." Makalah yang disajikan pada Sanctioning Panduan Asesmen dan Tutorial Akademik Mahapeserta didik dan diskusi rambu-rambu penyusunan perangkat asesmen dan Tutorial, Hotel Sahid, Surabaya, 28-30 April 2003. Surabaya: UNESA.

[11] Dahar, R,.W. (1996) Teori-Teori Belajar. Jakarta: Erlangga

[12] Gott, Foulds and Johnson. 2001. Science Investigations. Collins Educational: London

[13] Ibrahim, M. 2001. Model Pengembangan Perangkat Pembelajaran Menurut Jerold E. Kemp \& Thiagarajan. A. reference used in the overseas Fellowship Program Contextual Learning Materials Development Proyek Peningkatan Mutu SLTP Jakarta Direktorat Sekolah Lanjutan Tingkat Pertama Direktorat Jendral Pendidikan Dasar dan Menengah Departemen Pendidikan Nasional in Collaboration with the University of Washington College of Education, State University of Surabaya, State University of Malang, and LAPI-
ITB. Surabaya: Faculty of Mathematics and Science State University of Surabaya.

[14] Kemp, J.E. Morrison, G.R. Ross, S.M.1994. Designing Effective Instruction.New York: Macmillan College Publishing Company.

[15] Grinnell, R.M Jr. 1988. Social Work Research and Evaluation. Third Edition. Itasca, Illinois F.E. Peacock Publisher. Inc.

[16] Tawil, M. (2007). Pengembangan Asesmen Portofolio untuk mengases Kompetensi Fisika SMA Topik Suhu dan Kalor, Tesis, tidak diterbitkan. Surabaya: Universitas Negeri Surabaya.

[17] Riduwan, 2008. Metode dan Teknis Menyusun Tesis. Bandung: Alfabeta

[18] Meltzer, David E.2002. The relationship between mathematics preparation and conceptual learning gains in physics: a possible .hidden variable. in diagnostic pretest scores. Department of Physics and Astronomy, Iowa State University, Ames, Iowa 50011.

[19] Hobri. 2009. Metodologi Penelitian Pengembangan (Developmental Research). Jember: FKIP Universitas Jember. 